\title{
SUSTAINABLE DEVELOPMENT ASSESSMENT OF ZINC OXIDE PRODUCTION FOCUSED ON AGRIBUSINESS
}

\section{ANÁliSE DA AUDITORIA ECOLÓGICA DO ÓXIDO DE ZINCO NO AGRONEGÓCIO}

\author{
I. M. MACARRÃOO ${ }^{1, *}$, J. C. DUTRA ${ }^{1}$
}

${ }^{1}$ University Center of FEI, Department of Materials Engineering, São Bernardo do Campo, São Paulo, Brazil

${ }^{*}$ Corresponding author. University Center of FEI, Department of Materials Engineering, São Bernardo do Campo, São Paulo, Brazil, Phone: +55 1143532900 e-mail address: jdutra@fei.edu.br (J.C.Dutra).

\begin{tabular}{l} 
A R T I C L E I N F O \\
\hline Article history: \\
Received 2020-05-06 \\
Accepted 2020-10-20 \\
Available online 2020-10-20 \\
pa l a vr a $s$ - ch a ve \\
Óxido de zinco \\
Auditoria Ecológica \\
Caracterização \\
Sustentabilidade \\
$k$ e y wor $d s$ \\
Zinc Oxide \\
Eco Audit \\
Characterization \\
Sustainability
\end{tabular}

\begin{abstract}
A B S T R A C T
Agribusiness sectors have evolved to a highly diversified level, fertilizer being their main interest. These products are composed of macronutrients and micro ones essential to life. Zinc is an essential micronutrient, and it is present in fertilizers as zinc oxide. The present work is concerned with assessing, from the sustainable development viewpoint, the entire chain of production and transportation of zinc oxide. It is intended to establish an ecological audit of $\mathrm{ZnO}$ by the CES EduPack ${ }^{\circledR}$ software in six different scenarios. The scenario composed only of recycled material for furnace feeding was the one that spent the least energy of all and had the lowest carbon footprint. However, a scenario composed only of pure zinc was the one that spent more energy and had the highest carbon footprint. Transport was the highest consumer of energy and carbon footprint in all scenarios.
\end{abstract}

\section{R E S U M O}

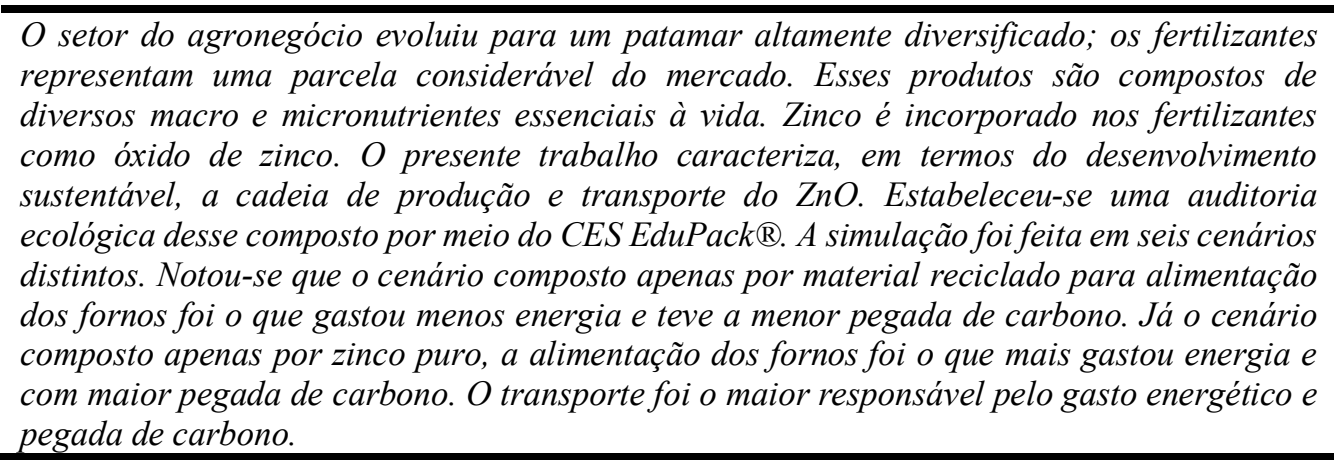




\section{INTRODUCTION}

Sustainable development is a very hot topic around the world (Harari, 2018; Marques Filho, 2018). Environmental issues have become a major and alarming concern in peopleôs lives. What was once apparently infinite has reached a critical point. Therefore, many authors (Djassemi, 2011; Javaid et al., 2015; Comitê, 2016; Koronis and Silva, 2018; Hamid and Lim, 2019; Liu et al., 2019) have studied the environmental impacts of different processes trying to restore part of our natural resources. People from different countries have been claiming for public policies to preserve natural resources. Despite being a global problem, as mentioned by Harari (2018), it has to be dealt with on a local basis.

As such, it is highly important that both carbon footprint and consumed energy be assessed in the process, in a general sense. Ashby, Brechbühl, Vakhitova e Vallejo (2019) have mentioned that any sustainable manufacturing has three fundamental components: planet, profit, and people, which are commonly represented by overlapping circles. Although these components are important, they consider that capitals are more useful to be seen when it comes to analyzing sustainability, i.e.: natural, human and social, and manufacture capitals. To make matters even more important, our present engineering courses are increasingly more aware of ecological aspects present in their decisions (Sullivan, 2010; Fergus et al., 2013).

Powder zinc oxide is produced from molten zinc or recycled zinc for the production of fertilizers (Alloway, 2008). As an oxide, it helps in stimulating seed germination and plant growth and it is known that zinc has tremendous effects in nutrition, playing an important role not only in recovering from infection and physical injury (Sillanpää, 1982; King et al., 2015) but also in their antifungal, ovicidal and larvicidal properties (Al-Dhabi; Arasu, 2018). According to Cakmak (2009), zinc is the most severe micronutrient deficiency along with vitamin $\mathrm{A}$ deficiency, and it is the principal cause of child death around the world. Panwar, Jain, Bhargaya, Akthtar and Yun (2012) have also highlighted the vital role zinc has in metabolic pathways in plant systems. The zinc ion is a cofactor in enzymatic reactions and participates in several biochemical cycles of plants, including photosynthesis and sugar formation, protein synthesis, fertility and seed production, growth regulation and defense against diseases (Aires, 2019).

The purpose of the present paper is to investigate both carbon footprint and consumed energy when zinc oxide is manufactured from molten zinc and recycled zinc in a plant located in Três Marias, a city in Minas Gerais, particularly in three different furnace arrangements as well as its distribution to their users. This is because not a single study has been done in Brazil with such concern. The strategy was to collect the necessary data from this plant and to use CES Edupack ${ }^{\circledR}$ software to characterize both aspects.

\section{ECOAUDIT AND CARBON FOOTPRINT}

Ecoaudit aims at quantifying material life ecological impact in its production, and each manufacturing step such as raw material, manufacture, transport, use, disposal and end-oflife potential may be analyzed (Granta Design, 2020). An ecological audit is an evaluation of material resources, energy, and carbon footprint associated with the useful life of a product and its end of life. This tool is found in CES Edupack ${ }^{\circledR}$ software, it is based on both $\mathrm{CO} 2$ emission and energy consumption for each compound, and different graphs can be drawn allowing their analysis related to zinc oxide production. It is a quick and easy tool that highlights the consequences of material changes, manufacturing routes, transport means, use, and disposal.

CES Edupack ${ }^{\circledR}$ also has a database connected to different official platforms from trustworthy public entities allowing a localized approach, i.e., several data from nations of the world that show the impact of product manufacturing on people and their social interaction, working conditions, the wellbeing of production plants expanding to suppliers and the impacted or involved community. It is also possible to access population data, gross national product, employment, political stability, and corruption control. However, these studies also require local information that may not be available to the public domain (Ashby et al., 2019). Ecoaudit tool in CES Edupack® also provides more specific information related to materials, processes, and economic values.

Djassemi (2011) provided a quantitative analysis of environmental-oriented material selection methodology, i.e., both materials selection and ecoaudit were analyzed. He showed that it is possible at first to select specific materials for a given product so they can be examined by their sustainability. One aspect mentioned in this paper was that the userôs knowledge is still required to achieve maximum benefits.

Another example of the use of the Ecoaudit tool from CES Edupack® can be found in Koronis and Silvâ̂ investigation (2018). This paper studied both cost and ecoimpact in green composites reinforced with plant-based fabrics. They studied different scenarios in the resin transfer molding process and considered jute as reinforcing, so cost could be smaller as well as reducing energy by $36 \%$ and $44 \% \mathrm{CO}_{2} / \mathrm{kg}$ when rami fabrics substitute glass fiber.

Javaid et al. (2015) characterized glass fiber/vinyl ester wind turbine rotor blade manufacturing and also studied this product ecoaudit. They found that the material phase comprised only $6.1 \% \mathrm{CO}_{2}$ while use was responsible for more than $90 \%$ in energy consumption and $\mathrm{CO}_{2}$.

Finally, Liu et al. (2019) compared different windturbine end-of-life options by using the Ecoaudit tool. This is because more concern is dedicated now to end-of-life turbine waste. Both glass-fiber reinforced and carbon-fiber-reinforced plastics were compared in terms of environmental impact. Although it is known that landfill and incineration are usually wind-turbines end-of-life processes, they investigated other processes, some industrial and other lab processes and showed 
that the relative impact of many end-of-life options is quite different: for glass-fiber-reinforced plastic, the best option is mechanical and chemical for recycling in the future while for carbon-fiber-reinforced plastic, fluidized bed for recycling gives the best results at present, but better be chemical recycling in the future. A mechanical recycling method involves cutting blades into pieces, shredding, and finally milling this waste into powder. Fluidized beds process, on the other hand, has a reactor working at high temperatures to decompose the polymeric part of carbon fiber reinforced shreds. The remaining fibers are collected (Meng, 2018).

Ecoaudit is upmost nowadays that undergraduate students are to be aware of their material selection and the environmental impact of this choice, as highlighted by Djassemi (2011). In doing so, students are not only required to select the best material for a given application but also to minimize environmental degradation over the whole life cycle of this material. His strategy was to divide the analysis in two phases: the first one being the material selection coupled with environmental auditing and then a quantitative analysis of the environmental impact of any chosen material.

What has become even more challenging in this analysis is when the social impact is taken into account. Asbhy et al. (2019) have shown this concern by highlighting that undergraduate students have to be aware of the social-impact audit so social life cycle assessment of products has to be present to analyze different scenarios. The categories to be investigated are workers, consumers, local community, society, and other value-chain actors. In this paper (Ashby et al., 2019), they gave two examples of how one of these categories may be studied by mapping different data sources that will be present in the next version of Granta Edupack ${ }^{\circledR}$ (Ansys Granta, 2019). In this case, despite selecting the best material for a given product and taking into account its ecoaudit numbers, it is additionally important to investigate how much the communities involved will be impacted in social terms, which gives the importance of this step for both undergraduate and graduate engineers. The only problem so far is that those sources of data are only among countries, which may be a difficult problem when it comes to domestic analysis.

The University Centre of FEI (FEI, 2018) has been studied this back to 1998 in undergraduate engineering courses such as materials engineering and mechanical engineering and has given a great effort to make students conscious of the importance of selecting materials based on Ashbyô methodology and keeping up-to-date to remind them of both the ecological aspects and social impact, the last one shortly.

\section{PRODUCTION PROCESS OF ZINC OXIDE}

Zinc oxide is produced in Três Marias plant by the French process, known to represent the largest share of production in industrial society as mentioned by Luptáková, Dymál ek, Peǵová, Jurkovil, Barborák e Stodola (2016). In this process, zinc and its alloys are combusted in rotary furnaces nominated as batteries (Caetano, 2019). It is possible to use two types of raw materials, SHG zinc (special high grade) $(99.995 \%$ purity) or SHG zinc combined with secondary materials (galvanizing or steel sludge with $96.5 \%$ purity), to feed the battery ovens. There is still a type of zinc sludge with higher purity that is called PW (prime western) and is present in the CES EduPack $®$ database, which will be fed to obtain the results.
The $\mathrm{ZnO}$ schematic process can be seen in Figure 1 developed by Avila, 2019. The first stage of this process is to feed the furnaces with liquid zinc or liquid zinc sludge (melting point $419.5^{\circ} \mathrm{C}$ ), and this raw material is heated to approximately $920^{\circ} \mathrm{C}$ by vaporizing the $\mathrm{Zn}$ and reacting with oxygen to form the $\mathrm{ZnO}$. Thus, the hood above the ovens filters the oxide and transports the particles to the separator box that separates the particles with the highest particle size (step 2), passing through large tubes that provide cooling, and the particles are driven to the bag filter where they are filtered for the last time so that all particles are homogeneous (step 3). Finally, they are transported to a silo where they are stored to be homogenized by the mixer later (step 4). Zinc oxide goes through the bagging process (step 5) and is ready to be sold.

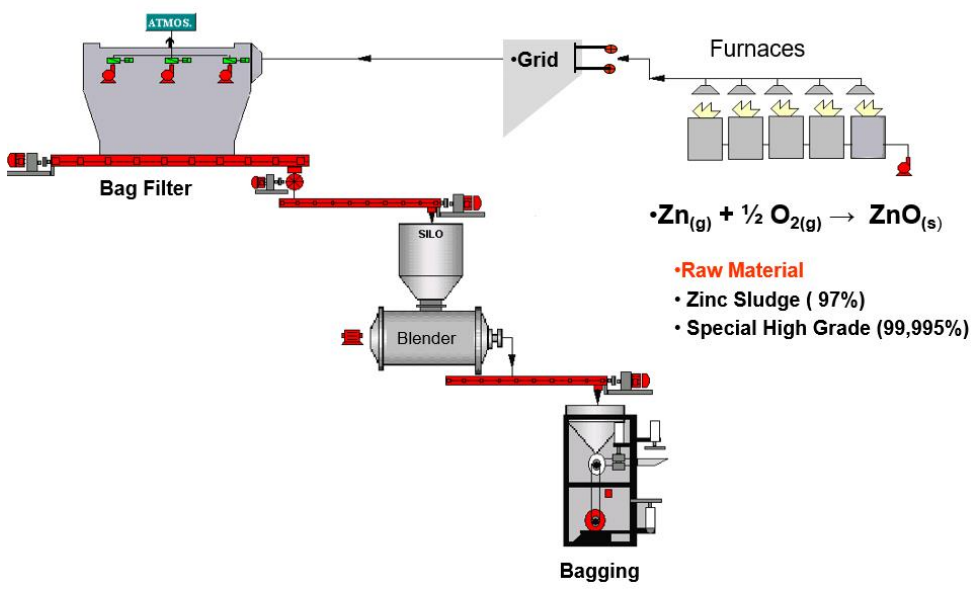

Figure 1 - Schematic process of $\mathrm{ZnO}$.

This process is able to control the purity and other oxide characteristics; it is possible to generate by this process different types of oxide that consequently receive different nomenclatures. The oxides sold to the fertilizer market that are obtained by this process are called ñzinc oxide FEò or ñzinc oxide FERTò (both names designed to abbreviate and indicate that this material is used in the area of fertilizers). As these materials are destined for the agricultural fertilizer market, they have a high degree of purity and strict control of contaminants, mainly of heavy metals, such as lead, cadmium, and copper, ensuring that their specifications meet the requirements of the sector.

Six different zinc oxide production scenarios were characterized to reproduce the various possibilities of zinc oxide production existing at the Nexa Recursos Minerais S.A plant, in Três Marias. Batteries 1 and 3 consist of 15 and 12 ovens, respectively, and it is possible to use pure zinc (SHG) produced in the company and secondary zinc, which came from the steel and galvanizing industry. The proportions of these two materials can be different. Therefore, it was chosen to analyze the scenario with $50 \%$ of each of these materials; $70 \%$ zinc sludge and $30 \%$ SHG zinc, and finally a scenario with $100 \%$ use of zinc sludge. Battery 4 was also analyzed; it consists of 12 ovens and can be fed only with SHG zinc; thus, the different scenarios were compared to each other.

One of the difficulties involved in this analysis was to adapt CES Edupack software and Ecoaudit to process zinc oxide as many uses of this tool were related to materials and products. These investigations do not use any quantitative approach towards carbon footprint in neither materials nor process. Djassemi (2011) had also found this problem. According to his 
study, it was difficult to incorporate data regarding environmental issues and evaluation of the life cycle of a given product.

\section{METHODOLOGY}

The first step was to carry out a preliminary simulation at CES EduPack® to understand what information would be crucial to obtain to simulate the ecological footprint of $\mathrm{ZnO}$ production processes for fertilizers. It was concluded that there was a need to collect more specific information such as the mass of raw material used in this process, how it is its end of life, what means of transportation are used to take this material to its destination, and what is the distance covered, how much energy is consumed in processing it and other production aspects.

On the Eco Audit screen, one must fill in the following information: in the óMaterial, manufacture, and end of lifeô blank, one must type the quantity and name of the material component. In the material column, it is possible to search the software database. Next, one must fill in the recyclable percentage of this material and its mass; it is again possible to search for options depending on the type of primary and secondary process. The removed percentage can also be reported to calculate material losses from the primary process. The one before the last column is used to calculate the end of life of material; so, it is necessary to choose one of the six given options. The options are landfill, downcycle, recycle, remanufacture, reuse, and none.

The energy and $\mathrm{CO}_{2}$ footprint associated with the end of a product's useful life are divided into two distinct contributions: disposal and end of life (EoL) potential seen in Figure 2. Disposal includes the cost of collecting the material/component at the end of its useful life and, when applicable, disposing it in a landfill and separating and sorting material ready for reprocessing by the proposed route to the end of its useful life. The EoL potential represents the savings or 'credits' that can be gained in future life cycles using the recovered material or components (Granta Design, 2020).

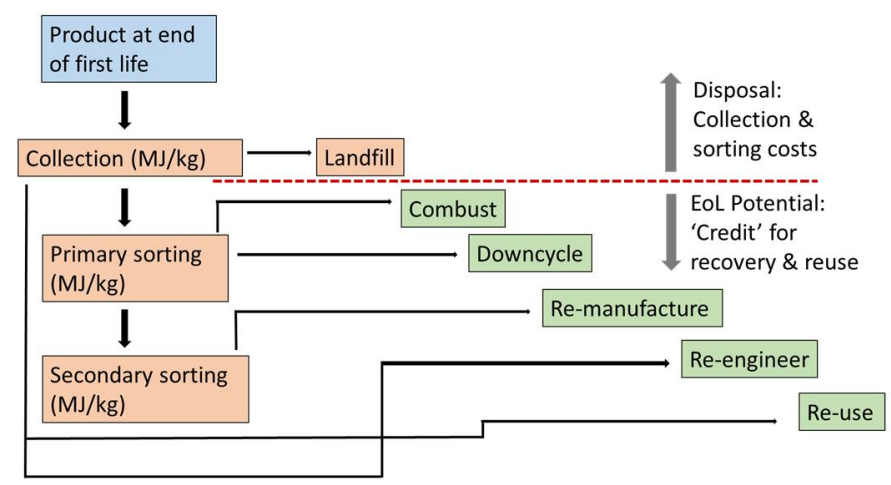

Figure 2 - Disposal and End-of-life cycle according to Eco Audit tool.

As the 'credit' associated with the recovery and reuse of material is outside the standard limits of the system for the life cycle of a product, the end-of-life potential is displayed as a separate life stage. Thus, this allows deetermining the ecological footprint of the product throughout the life cycle without counting the end of life and assessing the benefits of the various end-of-life options (achieved considering only the end-of-life potential phase). Finally, the last step deals with the material joining and finishing processes: it is necessary to write both the name of the component and its joining process, quantity, and units.

The following blanks for filling the Ecoaudit involve the means of transportation that one has to choose from the options given. If it is a truck, one needs to know how many axles are in a vehicle and its capacity for better results. Finally, one must fill the distance traveled.

The last blank to be filled in is áseâ this allows the calculation of energy costs in using the material or product studied. In the present investigation, áıseô was replaced by processing, i.e., the entire $\mathrm{ZnO}$ production chain and its costs were analyzed. First, the product life is filled in, that is, how long it lasts, its validity; then, one must inform which place this material is used, or which country is this material is studied.

The use phase is divided into two operating modes, static and mobile/dynamic. Static mode refers to products that are usually stationary, but they require energy to work as electric kettles, refrigerators, and power tools. Three parameters define this mode: product efficiency, power, and duty cycle.

Product efficiency is specified in the 'Energy input and output' drop-down menu. This specifies the energy conversion efficiency of the product and the environmental load associated with its energy source. The mobile/dynamic mode refers to transport systems, where mass has great influence on energy consumption. This mode is also defined by three parameters: type of transport, efficiency, and distance covered over the productô useful life. The type and efficiency of transport are specified in the 'Fuel type and mobility' drop-down menu. This determines the environmental load associated with transportation and its fuel. For products that operate in both modes, you can select both boxes. Finally, it is filled in how many days a year this material is used and how many hours a day to precisely calculate the energy expenditure (Granta Design, 2020).

The technical visit to the zinc oxide production plant located in the city of Três Marias, in Minas Gerais, was the following step. The purpose was to collect the necessary information to gather important information for the Ecoaudit tool as well as related documents and testimonies. It was also possible to know the production process of each battery used to produce zinc oxide and to understand the storage locations of raw materials.

After this visit, the necessary calculations for feeding the software began. It was necessary to search for other data, such as the calorific value of the oil used to heat the furnace. The simulations were carried out by studying different possible production scenarios and were compared with each other to obtain specific results for each parameter of the ecological footprint.

\section{RESULTS AND DISCUSSION}

The following shows the main results of the present investigation. First, Figures 3 and 4 reveal a comparison in consumed energy and carbon footprint, respectively, between batteries 1 and 3, which used 50\% pure zinc and 50\% recycled zinc, and battery 4, which used $100 \%$ SHG zinc. It can be seen that both carbon footprint and consumed energy are higher in battery 4 because it uses only SHG zinc as raw material. 


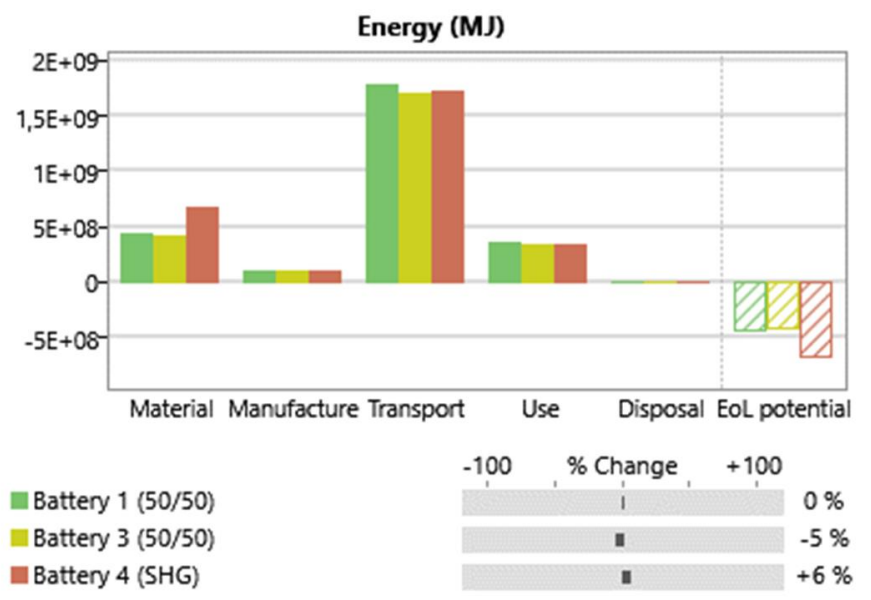

Figure 3 - Consumed energy of batteries 1,3 and 4, batteries 1 and 3 used as raw materials 50\% SHG zinc and $50 \%$ recycled zinc while battery 4 used $100 \%$ SHG zinc. Source: CES Edupack ${ }^{\circledR}, 2019$.

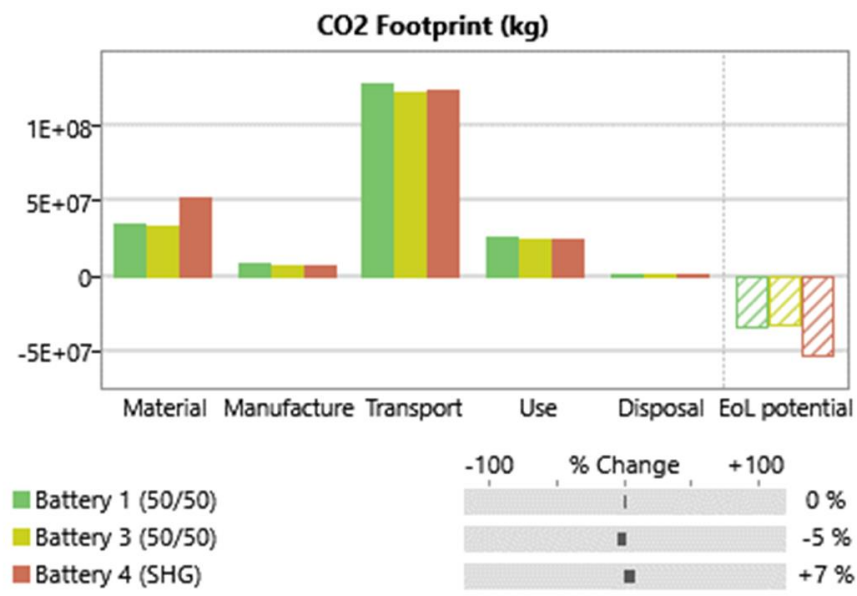

Figure $4-\mathrm{CO}_{2}$ footprint of batteries 1, 3 and 4, batteries 1 and 3 used as raw materials 50\% SHG zinc and 50\% recycled zinc while battery 4 used $100 \%$ SHG zinc. Source: CES Edupack ${ }^{\circledR}, 2019$.

There is a small difference between batteries 1 and 3 in these figures in the aspect materials because they have a different number of furnaces and also because battery 1 has higher productivity. Although the term use was originally thought of as the appropriate use of a product, the present investigation sees it differently. It is seen as the processing of $\mathrm{ZnO}$ and therefore shows that all of them have the same carbon footprint and consumed energy.

By and large, the highest contributor in both carbon footprint and consumed energy in this investigation is transport. This happens because in Brazil our transport system is mainly due to trucks. Although they are more flexible than other means of transport, they require more energy and, so far, there is no single integration or construction plan for railway lines on the routes of this product according to the Ministry of Infrastructure, in a 2020 document (Ministério da Infraestrutura, 2020; Secretaria Executiva, 2020).

The end of life follows the same proportion, i.e., battery 4 consumes more energy and has a higher carbon footprint and therefore has more credit since this product will be sold and used entirely by the fertilizing industry.

Second, Figures 5 and 6 show a comparison in consumed energy and carbon footprint, respectively, between batteries 1 and 3, which used 30\% pure zinc and 70\% recycled zinc, and battery 4 , which used $100 \%$ SHG zinc. It can be seen again that the principal responsible for consuming energy and carbon footprint is our transport for reasons already mentioned. It can also be observed in these figures that the use of recycled zinc consumes less energy and has lower carbon footprint.

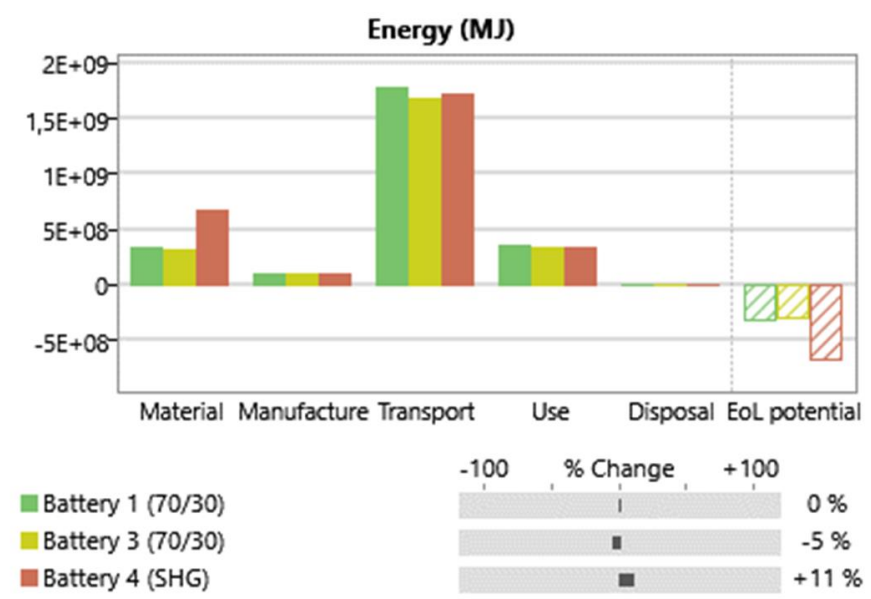

Figure 5 - Consumed energy of batteries 1, 3 and 4, batteries 1 and 3 used as raw materials $30 \%$ SHG zinc and $70 \%$ recycled zinc while battery 4 used $100 \%$ SHG zinc. Source: CES Edupack®, 2019.

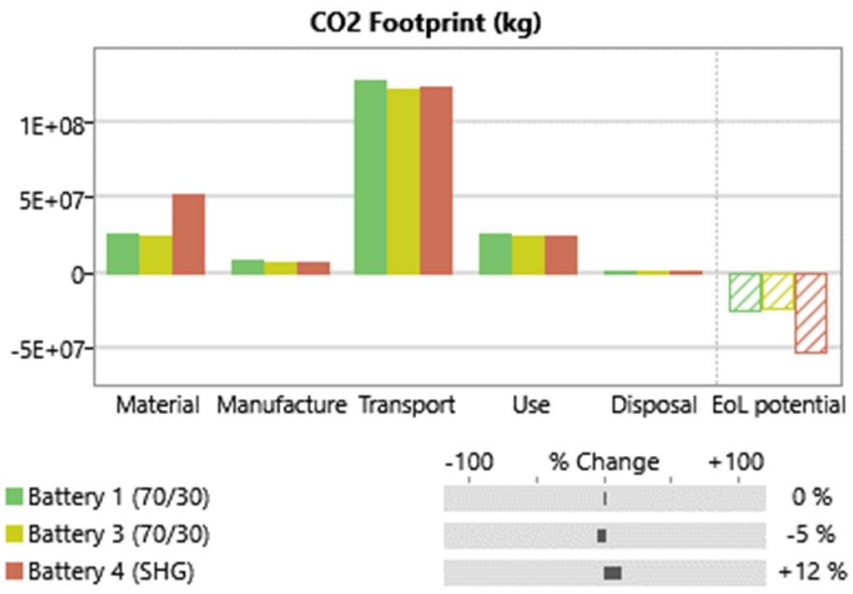

Figure 6- $\mathrm{CO}_{2}$ footprint of batteries 1, 3 and 4, batteries 1 and 3 used as raw materials $30 \%$ SHG zinc and $70 \%$ recycled zinc while battery 4 used $100 \%$ SHG zinc. Source: CES Edupack ${ }^{\circledR}, 2019$.

Finally, Figures 7 and 8 show a comparison in consumed energy and carbon footprint between battery 1 using different raw materials: $50 \%$ SHG zinc and 50\% recycled zinc, $30 \%$ SHG zinc and $70 \%$ recycled zinc, and finally $100 \%$ recycled zinc. It is possible to observe that the more recycled zinc is used in processing $\mathrm{ZnO}$, the less is their consumed energy and the lower their carbon footprint. This raw material comes from the galvanizing process and steelmakers. 
As for the other parameters, the results are the same because they do not depend on the processing of $\mathrm{ZnO}$. However, by observing their total consumed energy, using recycled zinc from the galvanizing process and steelmakers may contribute to lessening environmental impact and thereby reducing greenhouse gases, as can be seen in the word change bellow.

The percentages indicated in grey bars represent how much consumed energy or carbon footprint is valued when compared to the one in green. That means when battery 1 uses $50 \%$ recycled zinc $-50 \%$ SHG pure zinc (green) is compared to battery 1 using $70 \%$ recycled zinc and 30\% SHG pure zinc (yellow), the last one has $4 \%$ less consumed energy and carbon footprint. In the same way, when battery one uses only recycled zinc (red), its consumed energy and carbon footprint is $12 \%$ or $13 \%$ lower, respectively, than the first already mentioned.

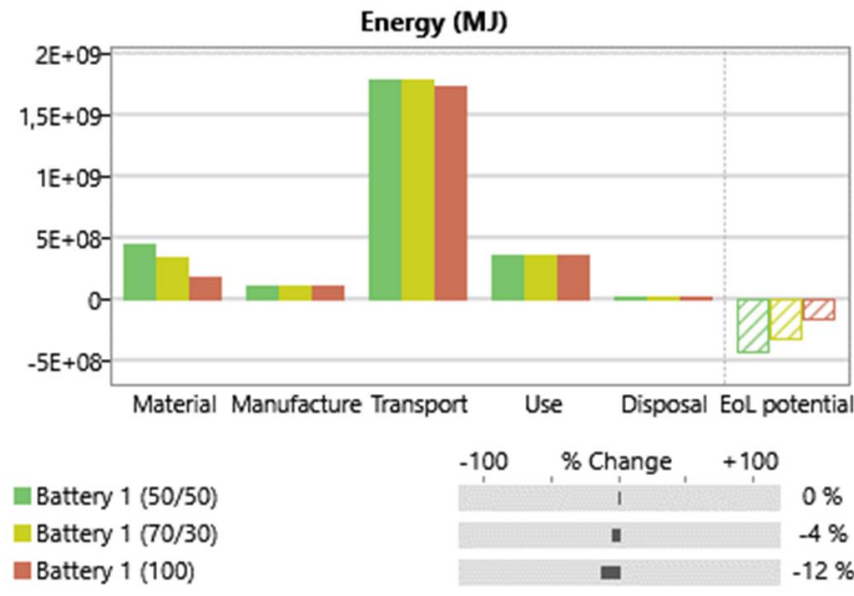

Figure 7 - Ecoaudit of zinc oxide of consumed energy for three different scenarios from battery 1. Source: CES Edupack®, 2019.

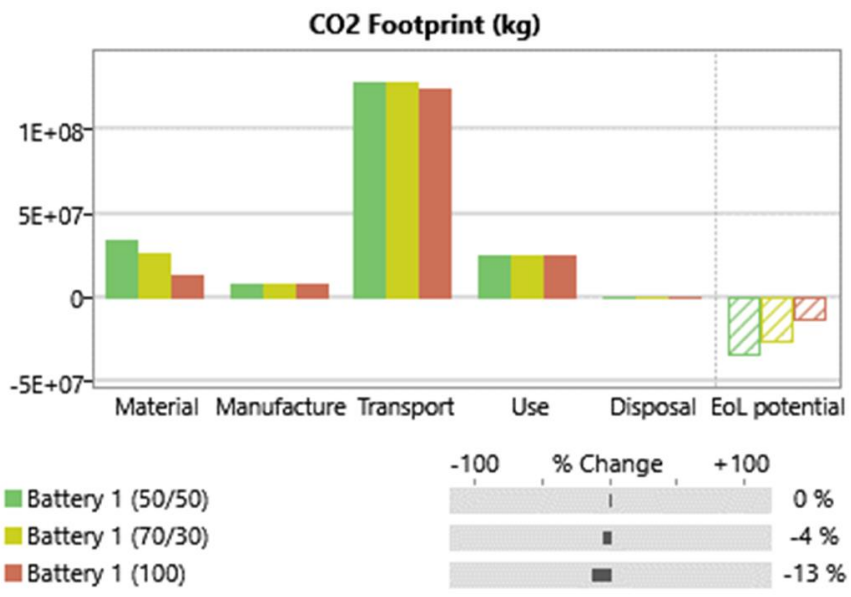

Figure 8 - Ecoaudit of zinc oxide in carbon footprint for three different scenarios from battery 1 . Source: CES Edupack ${ }^{\circledR}, 2019$.

Table 1 shows consumed energy and $\mathrm{CO}_{2}$ footprint for the scenarios investigated in this paper. It can be seen that a reduction in both energy and $\mathrm{CO}_{2}$ footprint of approximately $4 \%$ is possible when $70 \%$ of recycled zinc is used in batteries 1 and 3. It reaches $12 \%$ when $100 \%$ of recycled zinc is used in battery 1 .

Table 1 - Total Energy Consumption for first life (MJ year ${ }^{-1}$ ), energy consumption per kg of produced $\mathrm{ZnO}$, total carbon footprint (kJ year-1) and $\mathrm{CO}_{2}$ footprint per $\mathrm{kg}$ of produced $\mathrm{ZnO}$. The numbers between slashes (when present) represent the percentage of recycled zinc and SHG pure zinc, respectively.

\begin{tabular}{|c|c|c|c|c|}
\hline Scenario & $\begin{array}{l}\text { Total Energy (First life) } \\
\left(\text { MJ year }{ }^{-1}\right)\end{array}$ & $\begin{array}{l}\text { Energy Consumption } \\
\left(\mathrm{MJ} \mathrm{kg} \mathrm{ZnO}^{-1}\right)\end{array}$ & $\begin{array}{l}\text { Total Carbon Footprint } \\
\left(\mathrm{kg} \mathrm{year}^{-1}\right)\end{array}$ & $\begin{array}{l}\mathrm{CO}_{2} \text { Footprint }\left(\mathrm{kg} \mathrm{CO}_{2}\right. \\
\mathrm{kgZnO}^{-1}\end{array}$ \\
\hline $\begin{array}{l}\text { Battery 1: } \\
50 / 50\end{array}$ & $2.66 \times 10^{9}$ & 177.32 & $1.94 \times 10^{8}$ & 12.93 \\
\hline $\begin{array}{l}\text { Battery } 1 \\
70 / 30\end{array}$ & $2.55 \times 10^{9}$ & 169.98 & $1.86 \times 10^{8}$ & 12.40 \\
\hline $\begin{array}{c}\text { Battery } 1 \\
100\end{array}$ & $2.35 \times 10^{9}$ & 159.65 & $1.70 \times 10^{8}$ & 11.33 \\
\hline $\begin{array}{c}\text { Battery } 3 \\
50 / 50\end{array}$ & $2.54 \times 10^{9}$ & 177.34 & $1.85 \times 10^{8}$ & 12.92 \\
\hline $\begin{array}{c}\text { Battery } 3 \\
70 / 30\end{array}$ & $2.43 \times 10^{9}$ & 169.66 & $1.77 \times 10^{8}$ & 12.36 \\
\hline $\begin{array}{l}\text { Battery } 4 \\
\text { SHG }\end{array}$ & $2.82 \times 10^{9}$ & 195.10 & $2.08 \times 10^{8}$ & 14.39 \\
\hline
\end{tabular}


Table 2 - Energy Consumption for production of $\mathrm{ZnO}\left(\mathrm{MJ}_{\text {year }}{ }^{-1}\right)$, energy consumption per kg of produced $\mathrm{ZnO}$, total carbon footprint for production of $\mathrm{ZnO}\left(\mathrm{kJ}\right.$ year-1) and $\mathrm{CO}_{2}$ footprint per $\mathrm{kg}$ of produced $\mathrm{ZnO}$.

\begin{tabular}{|c|c|c|c|c|}
\hline Scenario & $\begin{array}{l}\text { Energy Consumption } \\
\text { for processing/use of } \\
\mathrm{ZnO}\left(\mathrm{MJ} \text { year }^{-1}\right)\end{array}$ & $\begin{array}{l}\text { Energy Consumption } \\
\text { for processing/use of } \\
\mathrm{ZnO}\left(\mathrm{MJ} \mathrm{kg} \mathrm{ZnO}^{-1}\right)\end{array}$ & $\begin{array}{l}\text { Carbon Footprint for } \\
\text { processing/use of } \mathrm{ZnO} \\
\left(\mathrm{kg} \mathrm{year}^{-1}\right)\end{array}$ & $\begin{array}{l}\mathrm{CO}_{2} \text { Footprint for } \\
\text { processing/use of } \mathrm{ZnO} \\
\left(\mathrm{kg} \mathrm{CO}_{2} \mathrm{~kg} \mathrm{ZnO}^{-1}\right)\end{array}$ \\
\hline $\begin{array}{c}\text { Battery 1: } \\
50 / 50\end{array}$ & $3.52 \times 10^{8}$ & 23.46 & $2.50 \times 10^{7}$ & 1.67 \\
\hline $\begin{array}{c}\text { Battery } 1 \\
70 / 30\end{array}$ & $3.52 \times 10^{8}$ & 23.46 & $2.50 \times 10^{7}$ & 1.67 \\
\hline $\begin{array}{c}\text { Battery } 1 \\
100\end{array}$ & $3.52 \times 10^{8}$ & 23.46 & $2.50 \times 10^{7}$ & 1.67 \\
\hline $\begin{array}{c}\text { Battery } 3 \\
50 / 50\end{array}$ & $3.36 \times 10^{8}$ & 23.46 & $2.39 \times 10^{7}$ & 1.67 \\
\hline $\begin{array}{c}\text { Battery } 3 \\
70 / 30\end{array}$ & $3.36 \times 10^{8}$ & 23.46 & $2.39 \times 10^{7}$ & 1.67 \\
\hline $\begin{array}{c}\text { Battery } 4 \\
\text { SHG }\end{array}$ & $3.39 \times 10^{8}$ & 23.45 & $2.41 \times 10^{7}$ & 1.67 \\
\hline
\end{tabular}

However, it is worthy to notice in Table 2 that the use of recycled zinc does not represent a high reduction in both energy consumption and $\mathrm{CO}_{2}$ footprint in producing $\mathrm{ZnO}$, independent from the battery investigated. It is worth mentioning that SHG pure zinc as a raw material may fabricate $\mathrm{ZnO}$ with the highest purity (FE oxide zinc), while recycled zinc may only produce $\mathrm{ZnO}$ with less purity (FERT oxide zinc). On the other hand, the use of recycled zinc may bring a 30\% saving in raw material cost, which is why it is generally preferred.

\section{CONCLUSIONS}

The following conclusions can be drawn from the present investigation: 1) Transport is the main responsible for both consumed energy and carbon footprint in all scenarios; 2) The quantity of consumed energy in raw material production is exactly the same as the end of life credit; 3) There is a 5\% difference between batteries 1 and 3 with $50 \%$ zinc sludge and $50 \%$ SHG zinc due to a higher mass in battery 1 for there are 3 more furnaces than battery 3 . The same result is found in a 70/30 scenario; 4) The end of life change in battery 3 is $5 \%$ lower than in battery 1 for $50 \%$ zinc sludge and $50 \%$ SHG zinc. The same result is found in 70/30 scenario;5) End of life change of battery 1 with $70 \%$ zinc sludge and $30 \%$ SHG zinc is $4 \%$ lower than the one from battery 1 with $50 \%$ zinc sludge and $50 \%$ SHG zinc; 6) The higher quantity of zinc sludge use in the production process of $\mathrm{ZnO}$, the lower are both the carbon footprint and the amount of consumed energy as it is the end of life potential.

\section{A C K N O W LED GEM E N T S}

The authors are grateful for the University Center of FEI for providing the software CES EduPack used in this investigation.

\section{R E F E R E N C E S}

AIRES, Carolina de Barros. Zinco, fator fundamental para aumento e melhora da produção agrícola: A deficiência desse micronutriente pode reduzir em até $40 \%$ o rendimento de culturas. 2009. Disponível em: $<$ https://www.agrolink.com.br/noticias/zinco--fatorfundamental-para-aumento-e-melhora-da-producaoagricola_94756.html>. Acesso em: 02 nov. 2019.

AL-DHABI, Naif; ARASU, Mariadhas Valan. Environmentally-Friendly Green Approach for the Production of Zinc Oxide Nanoparticles and Their AntiFungal, Ovicidal, and Larvicidal Properties. Nanomaterials, Saudi Arabia, v. 8, n. 7, p. 500-513, 6 jul. 2018. MDPI AG. http://dx.doi.org/10.3390/nano8070500.

ALLOWAY, Brian J. Zinco no solo e nutrição das culturas. São Paulo: Iza e Ifa, 2008. 256 p. Tradução de Sueli Monteiro.

ANSYS GRANTA. Granta Edupack. Versão 2019. [S.1.]: Ansys Granta, 2019.

ASHBY, Mike et al. Social Life-Cycle Assessment and Social Impact Audit Tool: a white paper. Cambridge: Ansys Granta Design, 2019. 21 p.

AVILA, Marcos Guilherme Correa. Fluxograma Básico do Processo. Três Marias, 2019. 8p.

CAetano, Mário. Processos de Obtenção do Óxido de Zinco. Disponível em: <https://www.ctborracha.com/borracha-sintesehistorica/materias-Primas/cargas/cargas-naonegras/oxido-de-zinco/processos-de-obtencao-de-oxidode-zinco/>. Acesso em: 01 dez. 2019.

CAKMAK, Ismail. Enrichment of fertilizers with zinc: an excellent investment for humanity and crop production in india. Journal Of Trace Elements In Medicine And Biology, Istanbul, v. 23, n. 4, p. 281-289, nov. 2009. Elsevier $\mathrm{BV}$. http://dx.doi.org/10.1016/j.jtemb.2009.05.002.

COMITÊ ORGANIZADOR DOS JOGOS OLÍMPICOS E 
PARALÍMPICOS RIO 2016 (Rio de Janeiro) (org.). Relatório de Gestão da Pegada de Carbono dos Jogos Rio 2016. 2014. Disponível em: https://pt.slideshare.net/isustentavel/relatrio-de-gestoda-pegada-de-carbono-dos-jogos-rio2016?from_action=save. Acesso em: 02 dez. 2019.

DJASSEMI, Manocher. A computer-aided approach to material selection and environmental auditing. Journal Of Manufacturing Technology Management, [S.L.], v. 23, n. 6, p. 704-716, 20 jul. 2012. Emerald. http://dx.doi.org/10.1108/17410381211253290.

FERGUS, Jeffrey W.; TWIGGE-MOLECEY, Christopher; MCGUFFIN-CAWLEY, James. Sustainability in Materials Education. Jom, [S.L.], v. 65, n. 8, p. 935-938, 6 jun. 2013. Springer Science and Business Media LLC. http://dx.doi.org/10.1007/s11837-013-0644-x.

GRANTA DESIGN (org.). About the Eco Audit Tool. Disponível em: http://support.grantadesign.com/resources/cesedupack/2 019/help/topic1.htm\#t=html\%2Feco\%2Feco_about.htm. Acesso em: 15 abr. 2020.

GRANTA DESIGN (org.). End of life calculations. Disponível em: http://support.grantadesign.com/resources/cesedupack/2 019/help/html/eco/ecodata_endoflife.htm. Acesso em: 15 mar. 2020.

HAMID, Nur Nabila Abdul; LIM, Jeng Shiun. Evaluation of processing route alternatives for accessing the integration of algae-based biorefinery with palm oil mill. Journal Of Cleaner Production, Johor Bahru, v. 212, p. 12821299, dez. 2018.

HARARI, Yuval Noah. 21 lições para o século 21. São Paulo: Companhia das Letras, 2018. 441 p. Tradução de Paulo Geiger.

JAVAID, Umair; KHAN, Zaffar M.; KHAN, M.B.; BASSYOUNI, M.; ABDEL-HAMID, S.M.-S.; ABDELAZIZ, M.H.; HASAN, Syed W. Ul. Fabrication and thermo-mechanical characterization of glass fiber/vinyl ester wind turbine rotor blade. Composites Part B: Engineering, [S.L.], v. 91, p. 257-266, abr. 2016. Elsevier BV. http://dx.doi.org/10.1016/j.compositesb.2015.12.034.

KING, Janet C; BROWN, Kenneth H; GIBSON, Rosalind s; KREBS, Nancy F; LOWE, Nicola M; SIEKMANN, Jonathan H; RAITEN, Daniel J. Biomarkers of Nutrition for Development (BOND)ठ Zinc Review. The Journal Of Nutrition, [S.L.], v. 146, n. 4, p. 858-885, 1 abr. 2015. Oxford University Press (OUP). http://dx.doi.org/10.3945/jn.115.220079.

KORONIS, Georgios; SILVA, Arlindo. Green Composites Reinforced with Plant-Based Fabrics: cost and ecoimpact assessment. Journal Of Composites Science, [S.L.], v. 2, n. 1, p. 8-29, 11 fev. 2018. MDPI AG. http://dx.doi.org/10.3390/jcs2010008.

LIU, Pu; MENG, Fanran; BARLOW, Claire Y.. Wind turbine blade end-of-life options: an eco-audit comparison. Journal Of Cleaner Production, [S.L.], v. 212, p. 1268-1281, mar. 2019. Elsevier BV. http://dx.doi.org/10.1016/j.jclepro.2018.12.043.

LUPTÁKOVÁ, N.; DYMÁlEK, P.; PEĞlOVÁ, F.; JURKOVIÍ, Z.; BARBORÁK, O.; STODOLA, J.. IMPACT OF RESIDUAL ELEMENTS ON ZINC QUALITY IN THE PRODUCTION OF ZINC
OXIDE. Si: Metalurgija , 2016.

MARQUES FILHO, Luiz César. Capitalismo e Colapso Ambiental. Campinas: Unicamp, 2018. 735 p.

MENG, Fanran; OLIVETTI, Elsa; ZHAO, Youyang; CHANG, Jiyoun Christina; PICKERING, Stephen J.; MCKECHNIE, Jon. Comparing Life Cycle Energy and Global Warming Potential of Carbon Fibre Composite Recycling Technologies and Waste Management Options. Acs Sustainable Chemistry \& Engineering, [s. l], p. 1-39, 21 jun. 2018.

MINISTÉRIO DA INFRAESTRUTURA (org.). Síntese - Setor Ferroviário. Disponível em: https://www.infraestrutura.gov.br/component/content/ar ticle.html?id=5380. Acesso em: 27 mai. 2020.

OôSUlLIVAN, Ad. "Eco-Logical" Engineering: A teachingresearch model to foster students' paradigm thinking of wastes as commodities. New Zealand: Australasian Journal Of Engineering Education, 2010.

PANWAR, Jitendra; JAIN, Navin; BHARGAVA, Arpit; AKHTAR, Mohd Sayeed; YUN, Yeoung-Song. Positive effect of Zinc Oxide nanoparticels on tomato plants: A step Towards developing ñNanofertilizersò. Internacional Conference On Environmental Research And Technology, Pinang, p. 348-352, jan. 2012.

Secretaria Executiva (org.). Acompanhamento das Realizações do Ministério da Infraestrutura. 2020. Disponível em: https://infraestrutura.gov.br/images/2020/documentos/0 2/Periodico-Minfra-Miolo.pdf. Acesso em: 27 mai. 2020.

SILLANPÄ̈̈, M. Micronutrients and the Nutrient Status os Soils: a global study, FAO Soils Bulletin No. 48, FAO, 1982, Rome. 